\title{
A Study of the Relationship Between Firm Age-at-IPO and Aftermarket Stock Performance
}

\author{
David T. Clark \\ The Leonard N. Stern School of Business \\ Glucksman Institute for Research in Securities Markets \\ Faculty Advisor: Eli Ofek \\ April 1, 2002
}




\section{Introduction}

The average age of a firm going public during the 1990's was the lowest the market has witnessed since World War I. ${ }_{\text {With a mean time from incorporation to }}$ public offering of roughly ten years, the average 1990's IPO was about one-third as old as a typical mid- $20^{\text {th }}$ century IPO. A useful model for understanding why IPO's went to market so young during this period has been offered by Jovanovic and Rousseau. ${ }^{\square}$ They view the duration of the pre-IPO waiting phase as the result of a trade off between firm learning and the opportunity cost related to delay to market. Prior to a firm's IPO, management refines the enterprise's idea and strategy, while early investors and creditors assess the firm's potential, risks and optimal deployment of capital. Since the post-IPO capital investment will be irreversible, this learning process is very important because it reduces the possibility of a costly mistake. Yet the pre-IPO learning period delays the realization of revenues for the firm, creating an opportunity cost that varies depending on the quality of the idea. The firm will therefore attempt to maximize net present value in terms of these two factors by finding the optimal time for its IPO. Holding all else equal, the better a firm's idea, product or business model, the greater the opportunity cost of delay, and the earlier the firm will go public. The low average age-at-IPO during the 1990's may therefore indicate an era of unusually promising firms.

Given this explanation, a reasonable question to ask is whether the market was able to accurately gauge the high potential of the firms in this period, particularly the youngest firms. Theoretically, in an efficient market, the aftermarket price of an IPO will almost immediately reflect the growth potential of the firm, based on all available

\footnotetext{
${ }^{1}$ Jovanovic, Boyan, and Peter L. Rousseau. "Why Wait? A Century of Life Before IPO.” NBER Working Paper No. 8081. (January 2001).

${ }^{2}$ Jovanovic and Rousseau.
} 
information. Average risk-adjusted returns going forward should match the market, regardless of the age-at-IPO of a firm. This study is designed to examine the relationship between the age of firms at IPO and long-run aftermarket performance. In effect, the study will test the efficiency of the market with regard to the IPO's during the 1991 to 1997 period by measuring three-year holding period excess stock returns relative to firm age-at-IPO. In light of the technology-heavy character of the recent IPO period, the study also segments data into technology and non-technology panels in order to ascertain if there is an age-performance relationship peculiar to technology firms.

Consistent with prior research, we find overall negative abnormal returns for the whole sample of IPO's during the study period. We also find that a statistically significant positive relationship exists between age-at-IPO and aftermarket performance for the overall sample in this period. After we disaggregate the data, we observe that the age-return relationship is different for technology and non-technology firms. Nontechnology firms exhibit a positive monotone relationship between firm age-at-IPO and abnormal returns, with a high degree of statistical significance. Among technology enterprises, on the other hand, very young firms outperformed older firms, particularly during the 1995 to 1997 IPO period. On the whole, the technology panel exhibited a statistically significant negative correlation between age and excess returns. Finally, an examination of distressed de-listing rates shows that younger firms, particularly young technology firms, were more likely to suffer extreme financial difficulty during the 1991 to 1997 period. 


\section{Data Selection and Methodology}

The sample data set for this study is comprised of 1,234 companies that had U.S. common stock initial public offerings between January 1, 1991, and December 31, 1997. The sample data has been gathered from two primary sources: the Securities Data Corporation (SDC) database, and the Center for Research in Security Prices (CRSP) database.

Firms were selected for the study if they satisfied two criteria: first, the SDC database had to have incorporation and IPO date information for the firm; second, CRSP had to have accurate price, return and de-listing data. Out of roughly 4,000 IPO's for the period $^{\text {目 }}$ 1,234 firms met these criteria.

Firms were classified into one of fourteen industry designations based on SIC codes and Yahoo.com profile descriptions. While some subjective judgment was required in the industry designation exercise, the result improves upon the SIC code designations because many technology-based companies receive peculiar coding in the 1987 SIC system. The data was segmented into two panels, technology firms and nontechnology firms, based on the fourteen industry designations. The technology panel combined the "hard" technology, "soft" technology, biotech and telecom industry categories, while the rest of the categories formed the non-technology panel.

Firm age-at-IPO was computed from the date of incorporation to the date of IPO, and is listed in the data in monthly units. Historically, IPO firms have been incorporated on average ten or more years after founding. ${ }^{⿴}$ The gap between the two began to close dramatically starting in the mid-1970's, and averaged only a year or two in the 1990's.

\footnotetext{
${ }^{3}$ www.marketdata.nasdaq.com.

${ }^{4}$ Jovanovic \& Rousseau.
} 
Regardless, incorporation data is far more accessible than founding data, so the study defines age-at-IPO with reference to date of incorporation rather than date of founding.

The study compiled holding period excess returns for the three-year period following the first month's closing price after each firm's IPO. Excess returns were calculated by comparing the firm's holding period return to the CRSP value-weighted total stock market index (NYSE + NASDAQ + AMEX) return for the same period. The excess return for each IPO is defined as follows:

$$
X_{t}=\left(\left(P_{t}-P_{o}\right) / P_{o}\right)-\left(\left(I_{t}-I_{o}\right) / I_{o}\right)
$$

where:

$X_{t} \quad=\quad$ the excess return for each IPO firm

$P_{t} \quad=\quad$ the closing price of the IPO security $t$ months after the offering, adjusted for stock dividends and splits;

$P_{o}=\quad$ the closing price of the IPO security at the end of the calendar month in which the offering was issued;

$I_{o}=\quad$ the value of the CRSP value-weighted total stock market index at the end of the calendar month in which the offering was issued;

$I_{t}=\quad$ the value of the CRSP value-weighted total stock market index $t$ months after the offering.

While most of the IPO's in the data set survived the three-year aftermarket period used in the study, some firms were de-listed prior to the $36^{\text {th }}$ month. For de-listed firms, the last CRSP stock price listing was used to calculate a holding period return for the security, measured against the market return for the same period.

The method used in this study for calculating aftermarket excess holding period returns implicitly assumes that the systematic risk of each IPO mirrors that of the CRSP whole market index. Unfortunately, this assumption is not valid for IPO firms. 
Academic research indicates that the systematic risk of IPO's is generally higher than that of a whole market index. For example, Ibbotson estimated the average IPO beta at 2.2, Reilly at 1.97 (relative to NASDAQ), and Buser and Chan at $1.54 .^{\text {G }}$ As a result of the higher average beta, the reported excess returns are upward-biased estimates of the riskadjusted abnormal returns.

Finally, distressed de-listing rates were calculated using de-listing and price information data from the CRSP database. A firm was considered a distressed de-listing if it traded at a price equal to or below one dollar in the period in which it was de-listed.

\section{Summary Data}

Table 1 shows the number of IPO's that occurred in each year from 1991 to 1997, and the number of IPO observations included in the study from each of those years. The percentage of IPO's included in 1996 and 1997 are higher than previous years because the SDC database has more incorporation data from more recent years.

Table 1: Total IPO's Per Year By Market and Study

\begin{tabular}{lrrrrrr}
\hline Year & NASDAQ & NYSE & Amex & Total & \# In Study & \% in Study \\
\hline 1991 & 320 & 49 & 11 & 380 & 66 & $17.4 \%$ \\
1992 & 442 & 80 & 6 & 528 & 85 & $16.1 \%$ \\
1993 & 520 & 97 & 11 & 628 & 164 & $26.1 \%$ \\
1994 & 444 & 82 & 13 & 539 & 127 & $23.6 \%$ \\
1995 & 476 & 72 & 9 & 557 & 121 & $21.7 \%$ \\
1996 & 680 & 88 & 18 & 786 & 322 & $41.0 \%$ \\
1997 & 494 & 87 & 22 & 603 & 349 & $57.9 \%$ \\
Total & 3376 & 555 & 90 & 4021 & 1234 & $30.7 \%$ \\
\hline \multicolumn{7}{l}{ Source: www.marketdata.nasdaq.com/asp/Sec3IPO.asp }
\end{tabular}

The age of firms, measured from incorporation date to issue date, varied from less than one month to over 1,000 months. The oldest firm was 1,151 months old at IPO. On

\footnotetext{
${ }^{5}$ Ibbotson, R.G., "Price Performance of Common Stock New Issues," Journal of Financial Economics (1975); Reilly, F.K., "New Issues Revisited," Financial Management (1977); Buser, S.A. and K.C. Chan, "NASDAQ/NMS Qualification Standards, Ohio Registration Experience and the Price Performance of Initial Public Offerings," Columbus, Ohio Department of Commerce and National Association of Securities Dealers (1987).
} 
average, health care firms for this period were the youngest at IPO, though the median real estate IPO was far younger than any other industry median. As one would expect, industrial and retail firms were, on average, the most mature at IPO. Table 2 indicates the average and median age of the included IPO's in each industry category.

\section{Table 2: Age Data By Industry (in months)}

\begin{tabular}{lrrr}
\hline Industry & Number of Offerings & Average Age & Median Age \\
\hline Agriculture & 27 & 189.6 & 60.0 \\
Biotech & 138 & 92.6 & 59.1 \\
Broadcast/Publishing & 26 & 80.5 & 52.4 \\
Consumer Products & 67 & 167.1 & 91.6 \\
Energy/Utilities/Mining & 34 & 185.9 & 74.5 \\
Financial & 98 & 131.5 & 52.8 \\
Health Care & 52 & 71.3 & 47.0 \\
Industrial & 162 & 221.0 & 111.3 \\
Real Estate & 62 & 113.5 & 9.9 \\
Retail & 88 & 207.4 & 111.8 \\
Service & 140 & 168.7 & 90.7 \\
Technology - Hard & 118 & 115.7 & 91.4 \\
Technology- Soft & 173 & 98.6 & 84.7 \\
Telecom & 49 & 94.0 & 66.9 \\
\hline
\end{tabular}

\section{Previous Research}

\section{Long-Run Aftermarket Performance of IPO's}

Numerous academic studies have been performed on the long-run aftermarket performance of IPOs. Virtually all of these studies have found substantial underperformance relative to either the market or a sample of matched firms. In addition, at least one study has examined the post-IPO operating performance of issuing firms. The following is a brief synopsis of the academic research on post-IPO performance.

Ritter (1991) documented significant 3-year IPO underperformance in the 1975 to 1984 period using a sample of 1,526 IPOs. ${ }^{6}$ Ritter's data set yielded average holding period returns of $34.5 \%$, versus a non-IPO sample, matched by industry and market

\footnotetext{
${ }^{6}$ Ritter, Jay. "The Long-Run Performance of Initial Public Offerings.” The Journal of Finance (March 1991).
} 
value, which yielded an average return for the same period of $61.9 \%$. This is a negative excess return of $26.4 \%$ using the method utilized in this study. He also found a positive monotone relationship between firm age and IPO aftermarket performance, with the oldest category of firms (over 20 years) showing positive abnormal returns. Ritter concludes that the market systematically overestimates the long-term growth opportunities of firms going public.

Aggarwal and Rivoli (1990) examined IPO 250-day aftermarket holding period

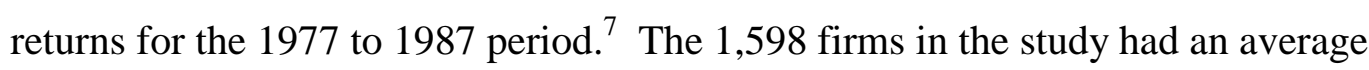
abnormal return relative to the NASDAQ market of $-13.73 \%$. The authors suggested that the average excess return was a conservative estimate because average IPO betas are greater than one, and the study period was dominated by a rising market. They conclude that the results provide support for the presence of fads in the IPO market.

Reilly (1977) found negative one-year aftermarket abnormal returns for IPOs in the early 1970's. ${ }^{8}$ He concluded, however, that the underperformance was due largely to the falling market of 1973-74, which, coupled with the higher systematic risk of the new issues, amplified the negative excess returns.

Buser and Chan (1987), on the other hand, found positive two-year marketadjusted returns of $11.2 \%$ in the 1981-1985 IPO aftermarket for NASDAQ/NMS-eligible offerings. ${ }^{\text {G }}$ The authors used the NASDAQ Composite Index to adjust the returns of the 1,087 firms in their sample. According to Ritter (1991), Buser and Chan is the only aftermarket performance study that does not find negative post-IPO abnormal returns.

\footnotetext{
${ }^{7}$ Aggarwal, Reena and Pietra Rivoli. "Fads in the Initial Public Offering Market?" Financial Management (1990).

${ }^{8}$ Reilly, F.K.. “New Issues Revisited.” Financial Management (1977).

${ }^{9}$ Buser, Stephen A. and K.C. Chan. "NASDAQ/NMS Qualification Standards, Ohio Registration Experience and the Price Performance of Initial Public Offerings." Columbus, Ohio Department of Commerce and National Association of Securities Dealer, Inc. (1987).
} 
Finally, Jain and Kini (1994) examined the post-IPO operating performance of 682 firms that IPO'd between 1976 and 1988, and documented a decline in the average operating performance of issuing firms after IPO, as measured by operating return on

assets. ${ }^{10}$ The authors conclude that the market appears to value recently issued securities based on the expectation that the firms' pre-IPO growth in fundamentals will continue, while in actuality performance tends to decline, often sharply.

\section{Pre-IPO Waiting Period Duration}

Jovanovic and Rousseau, as we mentioned in the introduction, modeled the IPO waiting-period as a learning phase, in which early investors, lenders and management assess the products, prospects and risks of the firm. The model focuses on the trade off between the risk-reducing nature of the learning period, and the opportunity cost associated with a delay to market. The greater the opportunity cost - in other words the better the idea or business model - the sooner a firm will go public. They argued that the 1990's IT-era firms went public at a young age because the technologies they introduced were too productive to be "kept out very long," and conclude that late $19^{\text {th }}$ century electrification era firms fit a similar pattern.

\section{Results}

\section{Overall Aftermarket Stock Performance}

Table 3 reports the average and median three-year holding period and excess return for the entire 1,234 firms in the sample. The average holding period return is substantially higher than the median, due to some extremely high-return firms such as

\footnotetext{
${ }^{10}$ Jain, Bharat A. \& Omesh Kini. "The Post-Issue Operating Performance of IPO Firms." Journal of Finance (1994).
} 
BEA Systems, Inc., which had the highest holding period return $(1,254.17 \%)$ and excess return $(1,177.98 \%)$ in the data set.

Table 3: Overall Holding Period and Excess Returns

\begin{tabular}{|l|r|r|}
\hline & Holding Period Return & Excess Return \\
\hline Average & $13.79 \%$ & $-45.60 \%$ \\
\hline Median & $-12.15 \%$ & $-69.69 \%$ \\
\hline
\end{tabular}

To examine the relationship between age-at-IPO and post-IPO performance, the study grouped the firms by age into quintiles. The results of the holding period excess return calculations for the whole sample are shown below in Figure 1, and in more detail in Table 4.

Figure 1: Post-IPO Performance by Quintile

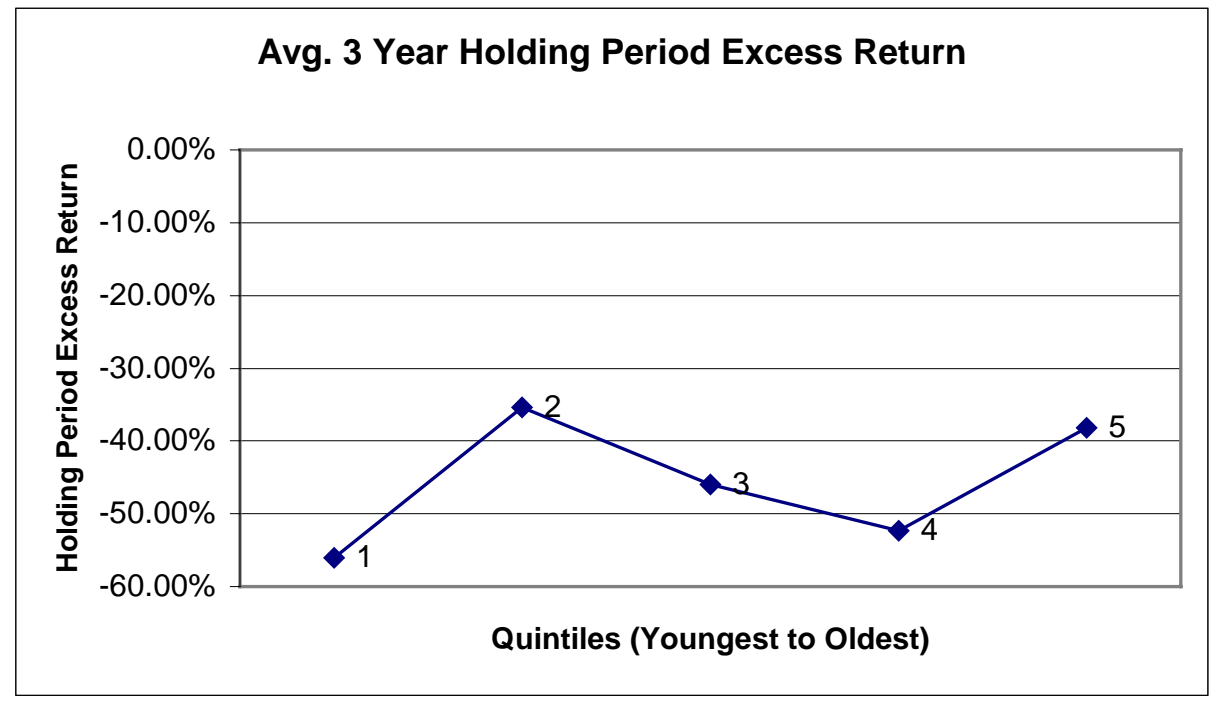

Table 4: Post-IPO Excess Holding Period Returns by Quintile

\begin{tabular}{rrrrrr}
\hline Quintile & \# of Observations Range in Months & Avg Age & Avg Excess Return \\
\hline 1 & 247 & 0.1 & 25.4 & 10.8 & $-56.05 \%$ \\
2 & 247 & 25.5 & 55.3 & 41.4 & $-35.38 \%$ \\
3 & 246 & 55.4 & 102.2 & 78.8 & $-45.99 \%$ \\
4 & 247 & 102.2 & 200.4 & 140.6 & $-52.35 \%$ \\
5 & 247 & 200.6 & 1151.5 & 433.6 & $-38.23 \%$ \\
\hline
\end{tabular}

The quintile data for the total sample reveals no clear correlation between firm age and post-IPO performance. Firms in the first (youngest) quintile, which average less 
than a year in age, showed negative excess returns of over $56 \%$ relative to the market, the worst performance by any quintile. Excess returns improved considerably in the second quintile, where firms averaged about 3.5 years of age. The oldest quintile had excess returns substantially better than the first quintile as well, though the range in months for the fifth quintile is so wide that it would be difficult to draw much of a conclusion from the result. Using a two-sample t-test to assess the difference between quintile 1 and the rest of the sample, we find that the difference in average excess return is marginally statistically significant. Exhibit 1 shows the results of the test.

In order to test for an overall relationship between age and excess return, we perform a regression analysis, using excess holding period return as the target variable. Excess returns in the sample have a long right-tailed distribution, with some extreme outliers that distort regression results. The analysis therefore censors the extreme outliers, attaching a value of $200 \%$ excess holding period return to any observation with an excess return over $200 \%$. There were approximately 40 observations that fit this criterion. Also, we have used a log (natural log) transformation for age-at-IPO, and have censored very low outliers by attaching a value of four months to any observation below four months of age-at-IPO. We used dummy variables for each industry designation (save one) and each IPO-year (save one) to control for those factors, and we performed the regression without an intercept. The regression results indicate that excess returns are positively associated with logged age-at-IPO at a statistically significant level for the overall sample (t-statistic of 1.83, p-value of 0.068 ). The coefficient for the logged age variable is 0.0316 , indicating that a $100 \%$ increase in firm age is associated with a $3.16 \%$ increase in three-year holding period excess return, holding everything else constant. See Exhibit 2 for more detailed information concerning the regression results. 


\section{Aftermarket Performance of Technology Firms}

The 1990's witnessed a technology-heavy IPO market, with many very young firms going public. The next sections of the study disaggregate the data into two broad panels in order to examine the relationship between age and performance for both technology and non-technology firms.

Figure 2 illustrates the relationship between technology firm age and excess stock returns for the 1991-97 IPO period. Unlike the overall data, the graphical representation of the average excess returns seems to indicate a negative correlation between age and aftermarket performance. The youngest technology firms (first quintile firms were less than two years old) in the panel dramatically outperformed every other quintile. The excess returns for all technology quintiles were superior (less negative) to the overall results, a reflection of the surging technology stock market during the 1990's. Table 5 shows the return data in more detail.

Figure 2: Technology Firm Returns Relative to Age-at-IPO

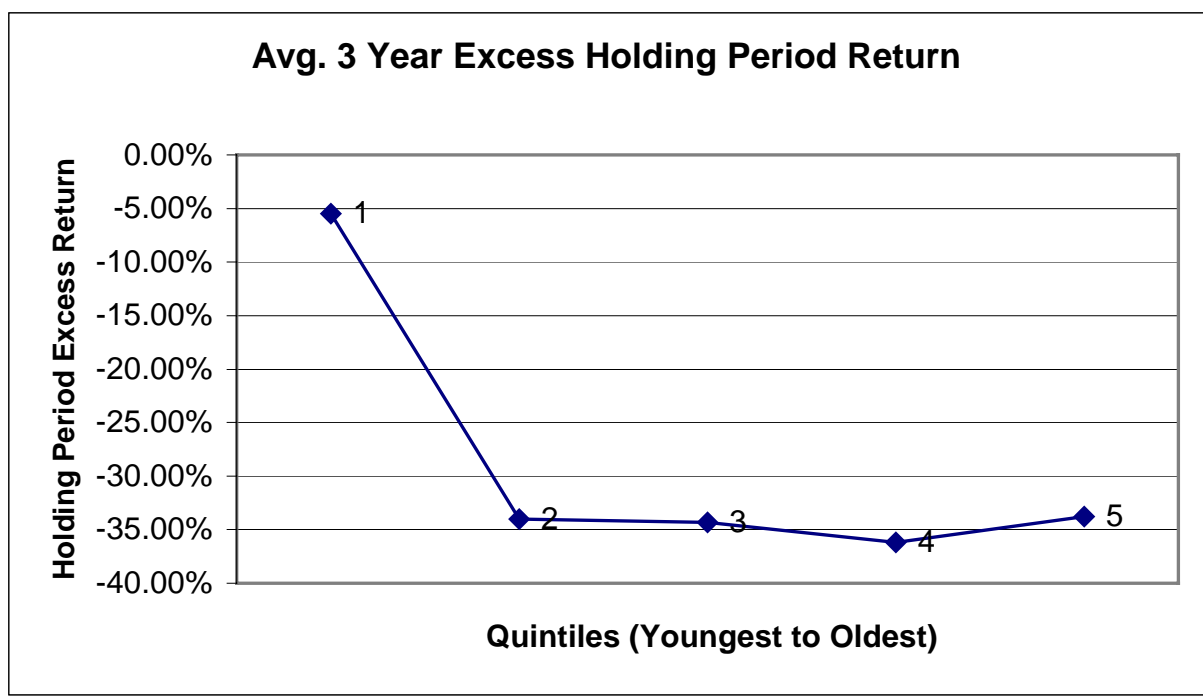


Table 5: Post-IPO Technology Firm Returns by Quintile

\begin{tabular}{rrrrrr}
\hline Quintile & \# of Observations & \multicolumn{2}{c}{ Range in Months } & Avg Age & Avg Excess Return \\
\hline 1 & 96 & 0.1 & 39.1 & 22.3 & $-5.49 \%$ \\
2 & 95 & 39.1 & 58.6 & 48.3 & $-34.01 \%$ \\
3 & 96 & 58.7 & 92.7 & 75.9 & $-34.31 \%$ \\
4 & 95 & 93.3 & 145.2 & 115.2 & $-36.19 \%$ \\
5 & 96 & 145.6 & 993.7 & 240.8 & $-33.79 \%$ \\
\hline
\end{tabular}

Despite the difference in average returns between the first quintile and the other quintiles, a two-sample t-test indicates that the gap is not statistically significant at the 0.95 confidence level, due largely to high standard errors. Exhibit 3 shows the details of the two-sample t-test. Nonetheless, the divergence in average returns is an interesting result. The superior average returns for young technology firms may indicate that the market during this period underestimated the growth potential of such firms (or overestimated the prospects of young firms less than old firms, since average returns are negative). Alternatively, the result may indicate that the industries in which these young firms operate have particularly high betas, producing relatively higher returns during the rising market of 1991-2000. In particular, the 1995-2000 period was an unusually bullish growth period for the market.

A regression for the technology panel, using the same characteristics as the regression for the overall sample, indicates a negative relationship between age and excess return that is statistically significant (t-statistic of 1.82 , p-value 0.70$)$. The coefficient of the logged age variable is -0.062 , indicating that a $100 \%$ increase in firm age is associated with a $6.2 \%$ fall in three year excess return, everything else held equal. Exhibit 4 shows more detail for this regression result.

The study further disaggregates the technology firm data into panels for the 199194 period and the 1995-1997 period, in order to ascertain whether the young technology 
firms outperformed older firms during the whole study period. The results appear in

Figure 3 and 4, and in more detail in Table 6 and 7.

Figure 3: Technology Firm Returns (1991-94)

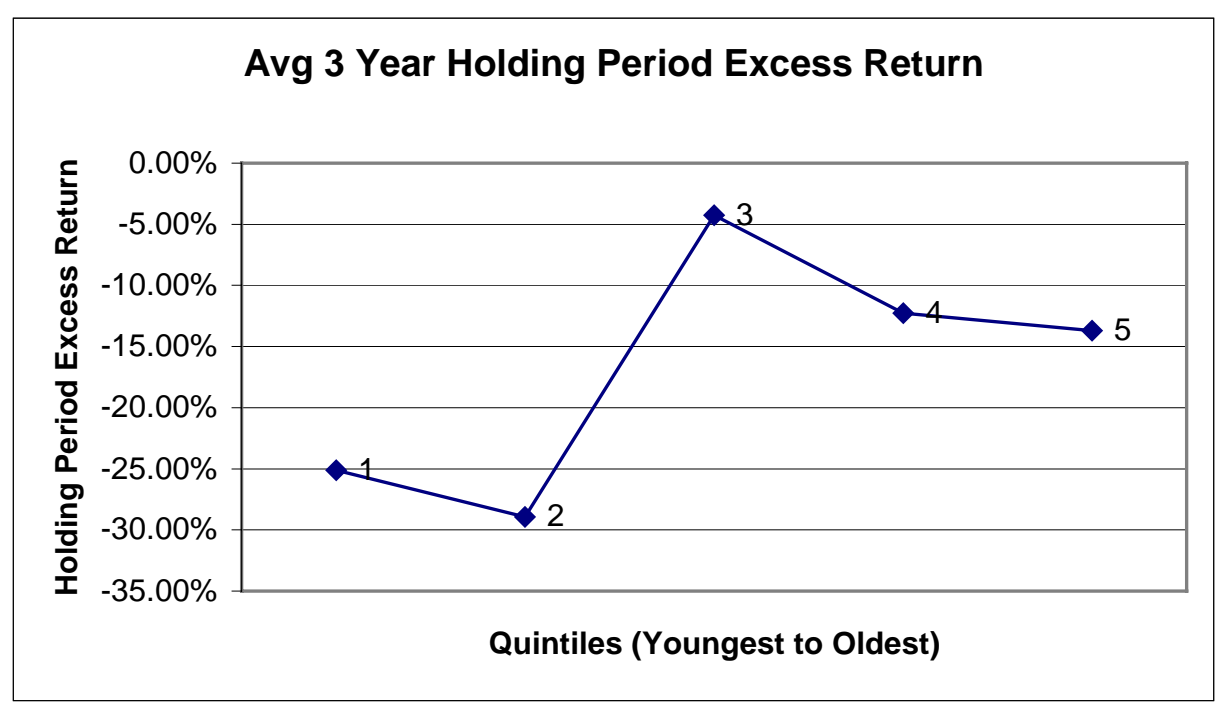

Figure 4: Technology Firm Returns (1995-97)

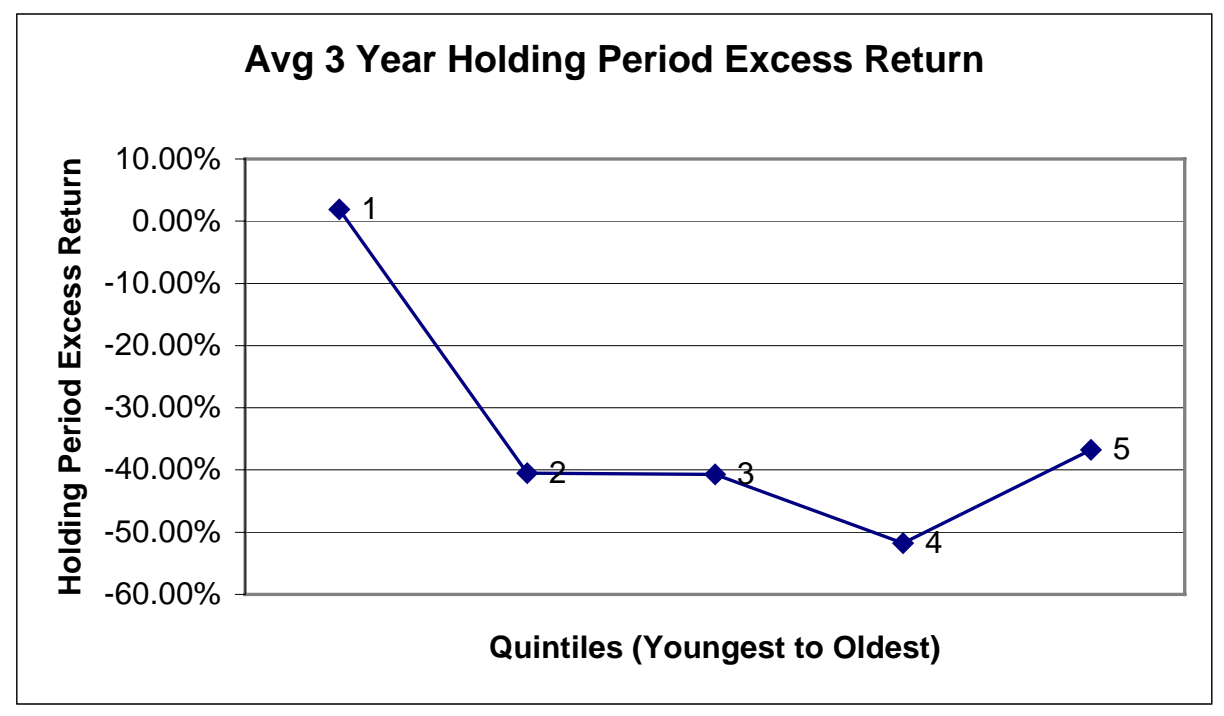

Table 6: Post-IPO Technology Firm Returns by Quintile (1991-94)

\begin{tabular}{rrrrrr}
\hline Quintile & \# of Observations & Range in Months & Avg Age & Avg Excess Return \\
\hline 1 & 28 & 1.6 & 43.1 & 27.8 & $-25.12 \%$ \\
2 & 27 & 43.1 & 66.3 & 53.0 & $-28.94 \%$ \\
3 & 28 & 66.4 & 96.9 & 80.7 & $-4.25 \%$ \\
4 & 27 & 97.1 & 133.7 & 113.3 & $-12.27 \%$ \\
5 & 28 & 135.5 & 993.7 & 232.2 & $-13.68 \%$ \\
\hline
\end{tabular}


Table 7: Post-IPO Technology Firm Returns by Quintile (1995-97)

\begin{tabular}{rrrrrr}
\hline Quintile & \# of Observations & Range in Months & Avg Age & Avg Excess Return \\
\hline 1 & 68 & 0.0 & 36.3 & 20.6 & $1.87 \%$ \\
2 & 68 & 36.6 & 57.3 & 46.4 & $-40.52 \%$ \\
3 & 68 & 57.6 & 91.5 & 73.7 & $-40.74 \%$ \\
4 & 68 & 91.6 & 148.2 & 116.2 & $-51.73 \%$ \\
5 & 68 & 148.4 & 704.8 & 243.9 & $-36.76 \%$ \\
\hline
\end{tabular}

Though the sample size of the earlier period is too small to assume statistical significance for the differences between quintiles (only 27 or 28 observations per quintile), the difference between the first quintiles in each panel relative to the other quintiles is nonetheless worth noting. The results here suggest that something peculiar to the late 1990's technology-driven bull market may have played a role in the better than expected results for young technology firms. Again, one possible explanation is that the betas for such firms are higher than older technology firms, and therefore returns were amplified during the dramatically rising market during the 1995-2000 period.

It is also possible that the market simply underestimated the prospects of these unusually young firms, relative to older firms, in the immediate aftermarket following IPO. Since the average age of IPO firms in the 1990's was the lowest in almost a century, the implication, in line with Jovanovic and Rousseau's model, is that the market potential of these very young firms may have been substantially higher than firms in prior IPO periods. Though many of the recent young IPO's showed remarkably high initial valuations, it is possible that the market still managed to underestimate these firms' potential relative to their older cohorts. 


\section{Aftermarket Performance of Non-Technology Firms}

The data for the non-technology panel indicates a positive monotone correlation between age and aftermarket performance, mirroring Ritter's result for IPO's in the 197584 period. Figure 5 illustrates this graphically, and Table 8 presents the non-technology panel results in more detail. A regression, again using the same characteristics as the regression for the overall sample, shows a highly statistically significant relationship between logged age-at-IPO and censored excess holding period return (t-statistic of 2.81, p-value of 0.005 ), and a coefficient for the logged age variable of 0.0467 , which suggests that, holding all else constant, a $100 \%$ increase in firm age is associated with a $4.67 \%$ rise in excess three year holding period returns. More detailed information for this regression result appears in the appendix in Exhibit 5.

\section{Figure 5: Non-Technology Firm Returns Relative to Age-at-IPO}

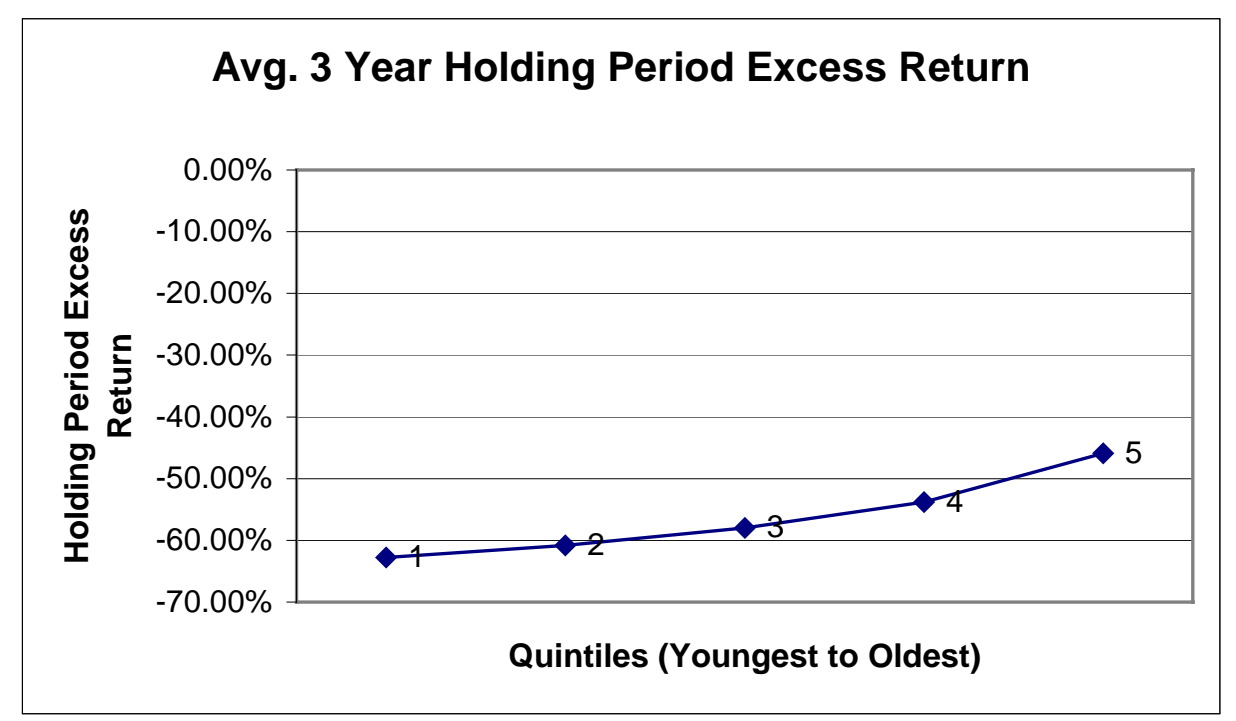


Table 8: Post-IPO Non-Technology Firm Returns by Quintile

\begin{tabular}{rrrrrr}
\hline Quintile & \# of Observations & \multicolumn{2}{l}{ Range in Months } & Avg Age & Avg Excess Return \\
\hline 1 & 151 & 0.1 & 15.8 & 7.0 & $-62.81 \%$ \\
2 & 151 & 15.9 & 52.3 & 33.8 & $-60.82 \%$ \\
3 & 152 & 52.5 & 112.0 & 82.0 & $-58.00 \%$ \\
4 & 151 & 112.4 & 260.3 & 172.5 & $-53.77 \%$ \\
5 & 151 & 261.2 & 1151.5 & 538.8 & $-45.92 \%$ \\
\hline
\end{tabular}

\section{Distressed De-listing Rates}

Figure 6 and Table 9 present the distressed de-listing percentages for the total sample, and each of the sector panels. The data matches what we would expect intuitively: younger firms are more likely to experience financial distress and de-list. This relationship between age-at-IPO and distressed de-listing holds up for both technology and non-technology firms, though young technology firms in particular appear more likely to experience post-IPO operating difficulty, with a rate over $8 \%$.

Figure 6: Percentage of Distressed De-Listings During Holding Period

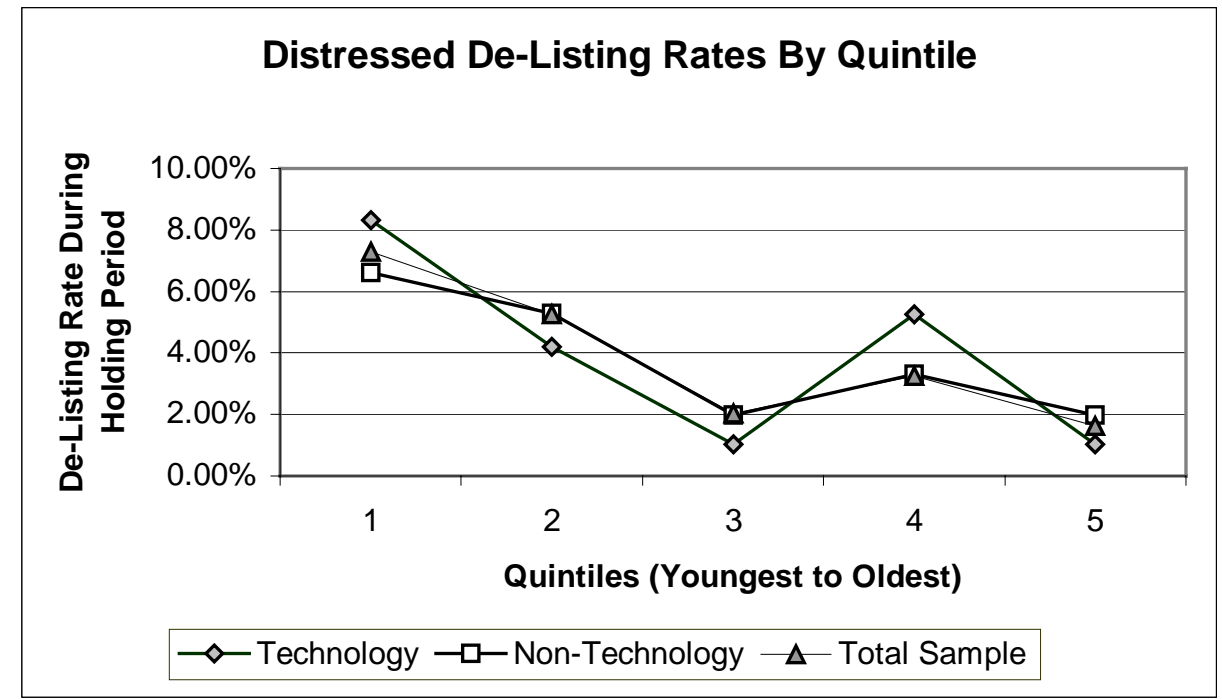

Table 9: Post-IPO Distressed De-Listing Rates By Quintile and Panel

\begin{tabular}{rrrr}
\hline Quintile & Technology & Non-Technology & Total Sample \\
\hline 1 & $8.33 \%$ & $6.62 \%$ & $7.29 \%$ \\
2 & $4.21 \%$ & $5.30 \%$ & $5.26 \%$ \\
3 & $1.04 \%$ & $1.97 \%$ & $2.03 \%$ \\
4 & $5.26 \%$ & $3.31 \%$ & $3.24 \%$ \\
5 & $1.04 \%$ & $1.99 \%$ & $1.62 \%$ \\
\hline
\end{tabular}




\section{Conclusion}

This study documented overall IPO-aftermarket underperformance during the 1991 to 1997 period, which is consistent with the majority of prior research conducted in other periods. In the aggregate, the data shows a statistically significant correlation between firm age-at-IPO and post-IPO excess returns. However, when the firms were disaggregated into technology and non-technology panels, the data suggested that the relationship between age and returns is different between the two categories.

Among technology enterprises, very young firms outperformed older firms, though the difference in return between the two age groups did not rise to a high level of statistical significance. We note that the performance of young technology firms may have been a peculiar result, distorted by the dramatically rising market of 1995-2000. The study also offers the alternative idea that the market may have underestimated the unusually strong prospects of this group of young technology IPO's relative to older technology firms.

Non-technology firms, on the other hand, exhibited a positive monotone correlation between firm age and excess holding period returns. A regression confirmed this positive relationship, established at a high degree of statistical significance.

Finally, the study examined the distressed de-listing rates for the three-year period following IPO for the data set, and found a consistent negative relationship between ageat-IPO and distressed de-listings for both technology and non-technology firms. 


\section{References}

Aggarwal, R. \& P. Rivoli. 1990. "Fads in the Initial Public Offering Market?” Financial Management.

Anderson, Seth \& T. Randolph Beard, Jeffrey A. Born. 1995. Initial Public Offerings:

Findings and Theories. Kluwer Academic Publishers.

Buser, Stephen A. and K.C. Chan. 1987. "NASDAQ/NMS Qualification Standards, Ohio Registration Experience and the Price Performance of Initial Public Offerings."

Columbus, Ohio Department of Commerce and National Association of Securities

Dealer, Inc.

Ibbotson, Roger G. 1975. "Price Performance of Common Stock New Issues.” Journal of Financial Economics.

Ibbotson, Roger G. \& Joey Sindelar, Jay R. Ritter. 1988. "Initial Public Offerings." Journal of Applied Corporate Finance.

Jain, Bharat A. \& Omesh Kini. 1994. "The Post-Issue Operating Performance of IPO Firms." Journal of Finance.

Jovanovic, Boyan \& Peter L. Rousseau. 2001. "Why Wait? A Century of Life Before IPO.” NBER Working Paper Series.

Lowry, Michelle \& G. William Schwert. 2001. "IPO Market Cycles: Bubbles or Sequential Learning?” Bradley Policy Research Center Working Paper.

Reilly, F.K. 1977. “New Issues Revisited.” Financial Management.

Ritter, Jay R. 1991. “The Long Run Performance of Initial Public Offerings.” Journal of Finance. 


\section{Exhibits}

\section{Exhibit 1}

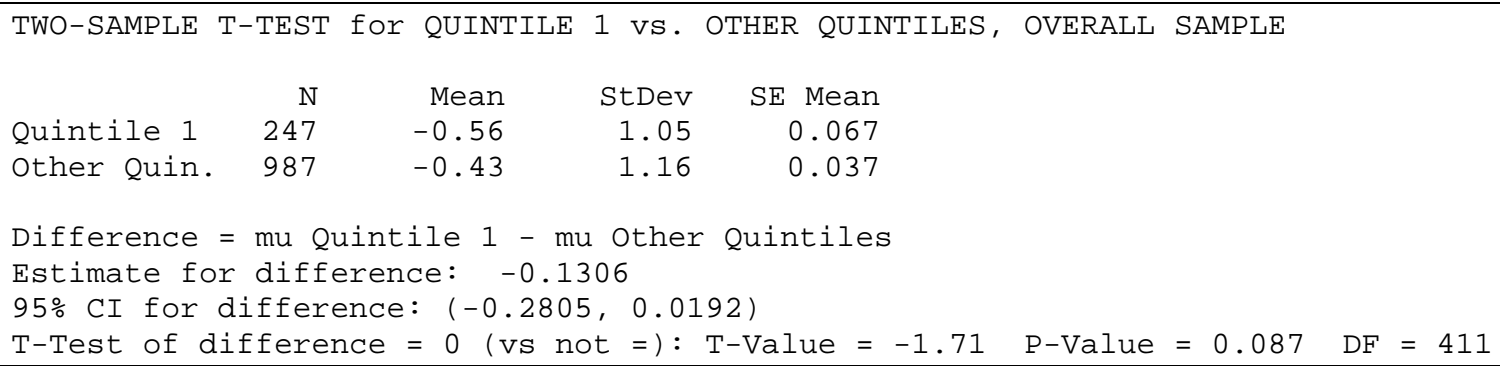

\section{Exhibit 2}

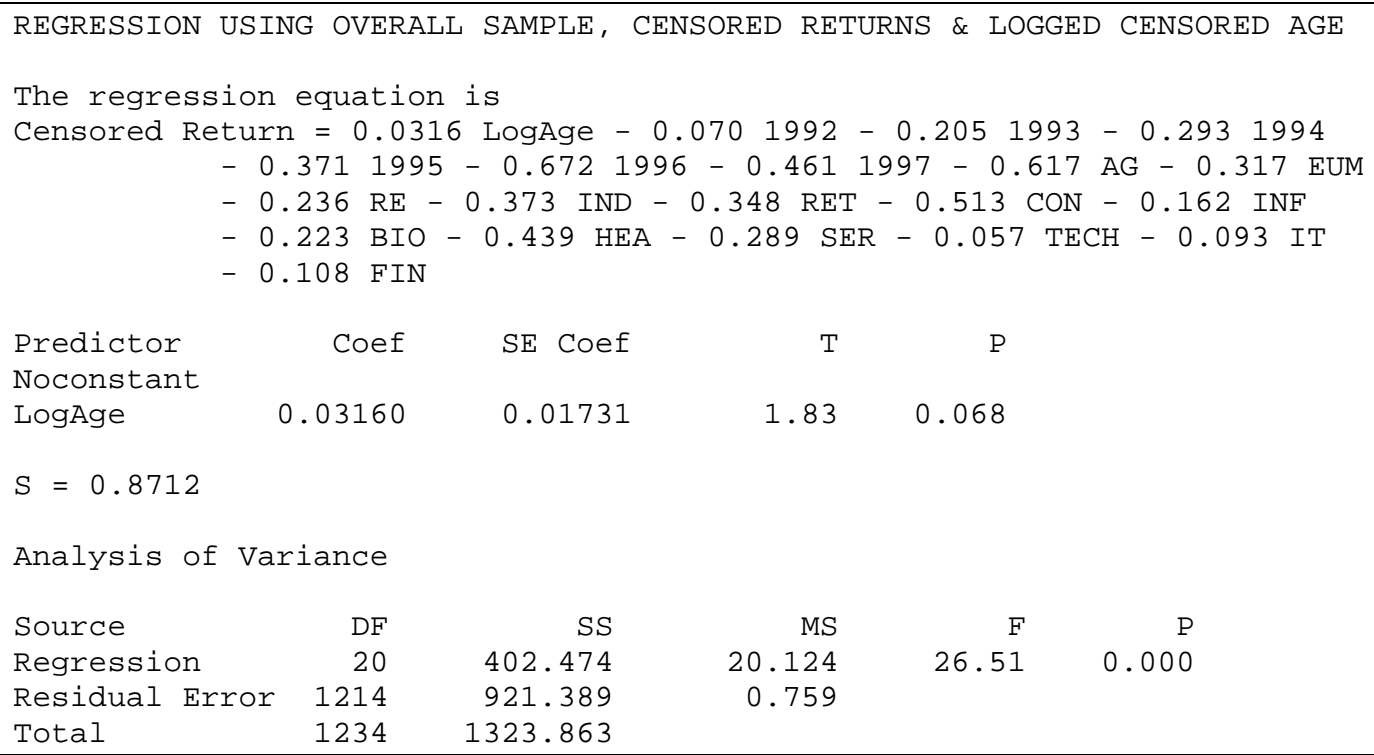

\section{Exhibit 3}

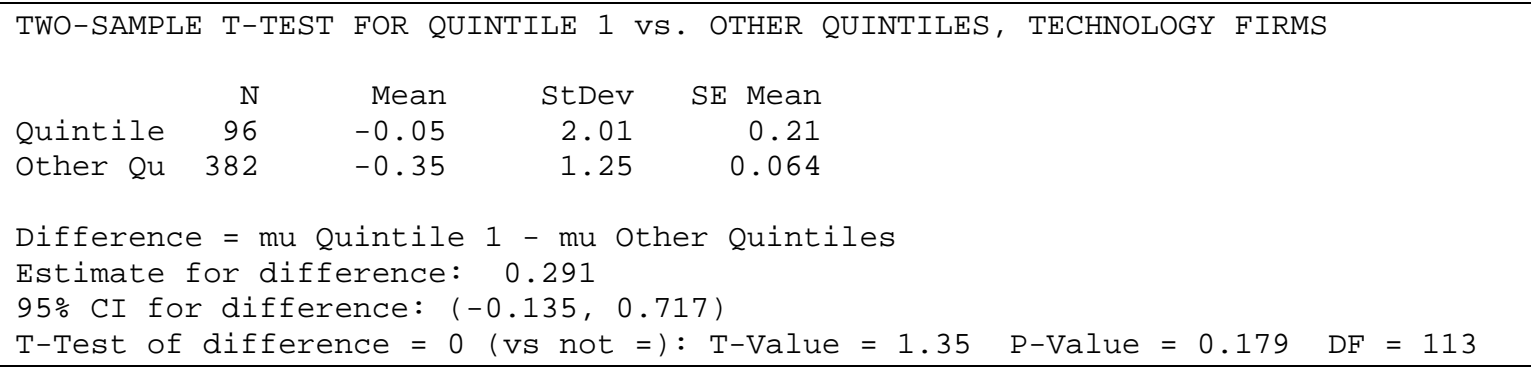




\section{Exhibit 4}

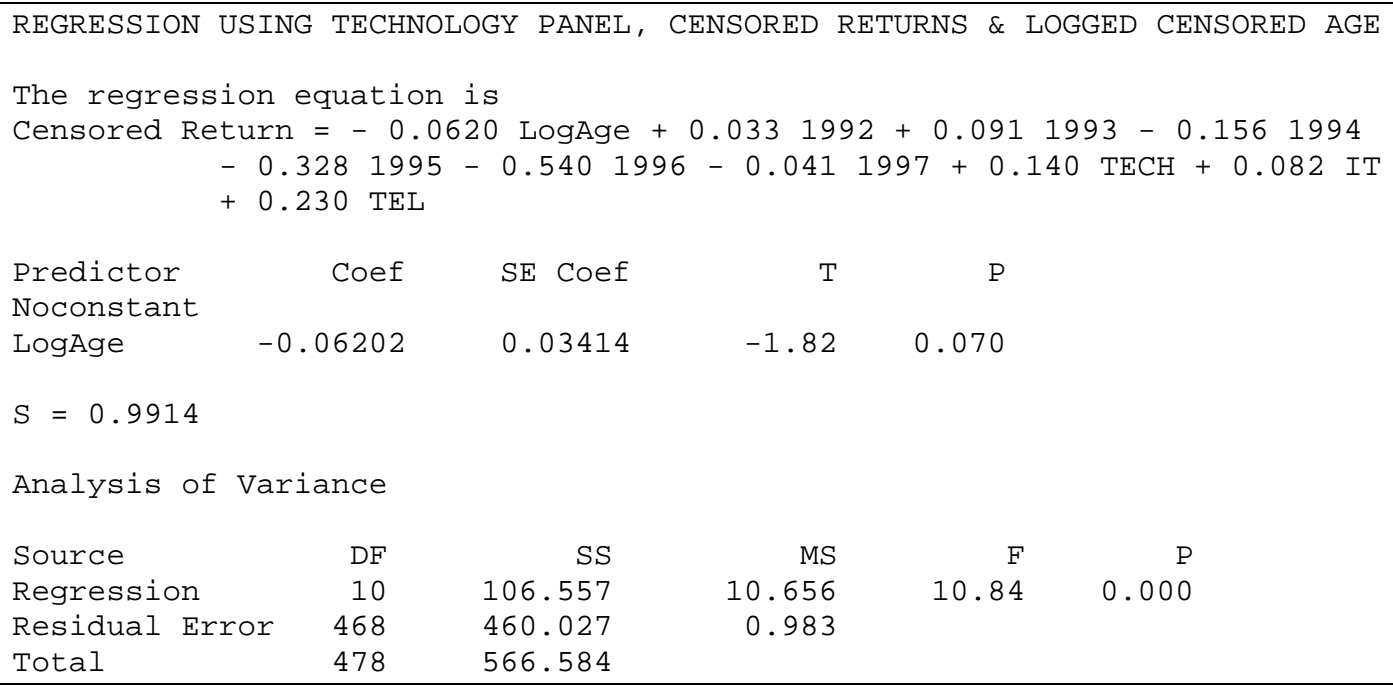

\section{Exhibit 5}

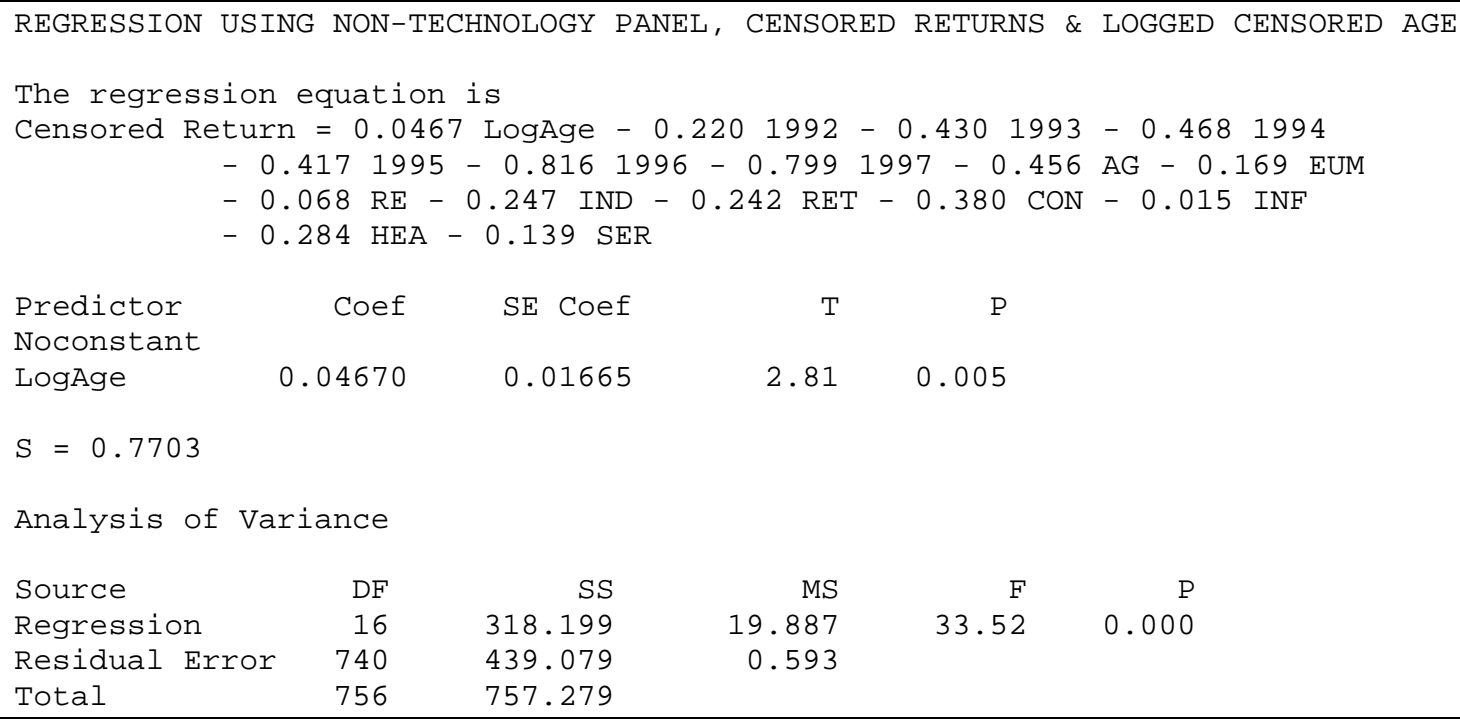

